DOI: $10.14720 /$ aas.2016.107.1.02

Agrovoc descriptors: safflower; carthamus tinctorius, varieties; seedlings, seeds, seed vigour; seed characteristics; seed weight; irrigation; water supply

Agris category code: F03, f06, f40

\title{
Changes in seed vigor of safflower (Carthamus tinctorius L.) cultivars during maturity in response to water limitation
}

\author{
Kazem GHASSEMI-GOLEZANI ${ }^{1 *}$, Morad MOHAMMADI ${ }^{1}$, Saeid ZEHTAB-SALMA ${ }^{1}$, Safar \\ NASRULLAHZADEH ${ }^{1}$
}

Received November 12, 2015; accepted February 06, 2016.

Delo je prispelo 12. novembra 2015, sprejeto 06. februarja 2016.

\section{ABSTRACT}

Seed development and vigor may be influenced by environmental stresses such as water deficit. Thus, this research was carried out to evaluate the effects of different irrigation treatments and harvest times on seed vigor of four spring safflower cultivars. Treatments were irrigations (irrigations after $70,100,130$ and $160 \mathrm{~mm}$ evaporation, respectively) in main plots and safflower cultivars (Faraman, Goldasht, Sina and Soffeh) in sub-plots. Seeds were harvested in 5 days intervals at 7 stages during development and maturity. The highest and the lowest seed and seedling masss at all harvests and irrigation treatments were recorded for Faraman and Sina cultivars, respectively. Seed vigor of safflower cultivars as measured by electrical conductivity of seed leachates and seedling dry mass decreased with decreasing water availability. Maximum seed mass and seedling dry mass and minimum electrical conductivity were obtained at 40-45 days after flowering, depending on irrigation interval and cultivar. Seed moisture content at these stages was $15-20 \%$, which is suitable for direct and mechanical harvesting and threshing.

Key words: Safflower, seedling and seed mass, seed vigor, water supply

\section{IZVLEČEK}

\author{
SPREMEMBE V VITALNOSTI SEMEN RAZLIČNIH \\ SORT ŽAFRANIKE (Carthamus tinctorius L.) MED \\ DOZOREVANJEM KOT ODZIV NA POMANJKANJE \\ VODE
}

Razvoj semen in njihova vitalnost sta odvisna od okoljskih stresov kot je tudi pomanjkanje vode. $\mathrm{V}$ tej raziskavi so bili ovrednoteni učinki različnih namakanj in časa žetve na vitalnost semen štirih jarih sort žafranike. Obravnavanja so bila namakanje (namakanje po $70,100,130$ in $160 \mathrm{~mm}$ evaporacije) na glavnih ploskvah in štiri sorte žafranike na podploskvah (Faraman, Goldasht, Sina in Soffeh). Semena so bila vzorčena $\mathrm{v}$ intervalu petih dni $\mathrm{v}$ sedmi stopnji razvojne faze in zrelosti. Največja in najmanjša masa semena in kalic sta bili pri vseh vzorčenjih in časih namakanja zabeleženi pri sortah Faraman in Sina. Vitalnost semen sort žafranike, izmerjena kot električna prevodnost izlužkov vode, $\mathrm{v}$ kateri so bila namakana semena in suha masa kalic sta se zmanjševali z upadanjem razpoložljivosti vode. Največja masa semen in suha masa kalic ter najmanša električna prevodnost izlužkov so bile izmerjene 40-45 dni po cvetenju, odvisno od intervala namakanja in sorte. Vsebnost vode $\mathrm{v}$ semenih je bila $\mathrm{v}$ tem obdobju 15-20\%, kar je ugodno za neposredno mehansko žetev, mlačvo in shranjevanje.

Ključne besede: žafranika, masa semen in kalic, vitalnost semen, oskrba $\mathrm{z}$ vodo

\section{INTRODUCTION}

Environmental factors during seed-filling period and even during flowering stage can widely affect seed yield and quality of oilseed crops (Monotti,
2003). Among all these environmental factors, drought stress is an important limiting factor for plant growth and yield, and may influence the

\footnotetext{
1 Department of Plant Eco-physiology, Faculty of Agriculture, University of Tabriz, 51666-16471, Tabriz, Iran

* Corresponding author: golezani@gmail.com
}

This research article based on a work for $\mathrm{PhD}$ degree. 
quality of safflower. Coincidence of water stress with reproductive stages of different crops reduces duration of flowering and seed filling and consequently lowers the number of seeds per plant, mean seed weight and seed yield per unit area (Ghassemi-Golezani and Mazloomi-Oskooyi, 2008; Ghassemi-Golezani et al., 2010). The deleterious effects of water limitation on field performance of crops may be reduced by cultivation of high vigor seeds (Sun et al., 2007).

High and rapid field emergence are essential to obtain an adequate plant stand in order to gain an advantage of the growing season before the onset of the severe drought stress late in the season (TeKrony and Egli, 1991). Stage of maturity at harvest is one of the most important factors that can influence the vigor of seeds (Demir et al., 2008). Maximum seed vigor on the mother plant may be achieved at the end of seed filling phase (mass maturity) which is also described as physiological maturity (Harington, 1972; Ghassemi Golezani et al., 2011b) or after mass maturity (Ghassemi-Golezani and MazloomiOskooyi, 2008; Ghassemi-Golezani et al., 2011a), depending on species and seed testing methods (Tekrony and Egli, 1997; Ghassemi-Golezani and Hosseinzade-Mahootchi, 2009).

Vieira et al., (1992) reported that drought stress had no significant effect on soybean seed germination and vigor. In contrast, GhassemiGolezani et al. (2012b, 2015) showed that water deficit led to significant reductions in seed vigor of soybean and maize. However, the effects of water limitation and harvest time on seed vigor of safflower are poorly understood. Thus, this research was carried out to evaluate changes in seed vigor of safflower cultivars under well and limited irrigation conditions in order to determine the stage at which maximum seed vigor is attained.

\section{MATERIALS AND METHODS}

The field experiment was conducted at the Research Farm of the University of Tabriz, Iran (latitude $38.05^{\circ} \mathrm{N}$, longitude $46.17^{\circ} \mathrm{E}$, Altitude $1360 \mathrm{~m}$ above sea level) in 2013. The climate was characterized by mean annual precipitation of $245.75 \mathrm{~mm}$, mean annual temperature of $10{ }^{\circ} \mathrm{C}$, mean annual maximum temperature of $16.6^{\circ} \mathrm{C}$ and mean annual minimum temperature of $4.2^{\circ} \mathrm{C}$. The experiment was arranged as split plot based on randomized complete block design in three replicates, with irrigation treatments $\left(\mathrm{I}_{1}, \mathrm{I}_{2}, \mathrm{I}_{3}, \mathrm{I}_{4}\right.$ for irrigation after $70,100,130$ and $160 \mathrm{~mm}$ evaporation from class $\mathrm{A}$ pan, respectively) in main plots and cultivars $\left(\mathrm{C}_{1}\right.$; Faraman, $\mathrm{C}_{2}$; Goldasht; $\mathrm{C}_{3}$; Sina and $\mathrm{C}_{4}$; Soffeh) in sub plots. Seeds were harvested in 5 days intervals at 7 stages during their development and maturity. The field plan and experimental arrangement are shown in figure 1 .

North

\begin{tabular}{|c|c|c|c|c|c|c|c|c|c|c|c|}
\hline & \multirow{2}{*}{$\mathbf{R}_{1}$} & $I_{2}$ & $\mathrm{C}_{3}$ & $\mathrm{C}_{4}$ & $\mathbf{C}_{1}$ & $\mathrm{C}_{2}$ & $I_{3}$ & $\mathrm{C}_{4}$ & $\mathrm{C}_{1}$ & $\mathrm{C}_{2}$ & $\mathrm{C}_{3}$ \\
\hline & & $I_{4}$ & $C_{1}$ & $\mathrm{C}_{3}$ & $\mathrm{C}_{4}$ & $\mathrm{C}_{2}$ & $I_{1}$ & $\mathrm{C}_{2}$ & $\mathrm{C}_{3}$ & $\mathrm{C}_{4}$ & $\mathrm{C}_{1}$ \\
\hline \multirow{4}{*}{ West } & \multirow{2}{*}{$\mathbf{R}_{2}$} & $\mathbf{I}_{\mathbf{3}}$ & $\mathrm{C}_{1}$ & $\mathrm{C}_{4}$ & $\mathbf{C}_{2}$ & $\mathbf{C}_{3}$ & $I_{1}$ & $\mathrm{C}_{3}$ & $\mathbf{C}_{4}$ & $\mathrm{C}_{2}$ & $C_{1}$ \\
\hline & & $I_{4}$ & $\mathrm{C}_{4}$ & $\mathrm{C}_{3}$ & $\mathbf{C}_{1}$ & $\mathrm{C}_{2}$ & $I_{2}$ & $\mathrm{C}_{1}$ & $\mathrm{C}_{2}$ & $\mathrm{C}_{3}$ & $\mathrm{C}_{4}$ \\
\hline & \multirow{2}{*}{$\mathbf{R}_{\mathbf{3}}$} & $\mathbf{I}_{1}$ & $\overline{C_{2}}$ & $\overline{C_{4}}$ & $\overline{C_{1}}$ & $\overline{C_{3}}$ & $\mathbf{I}_{4}$ & $\mathrm{C}_{2}$ & $\mathrm{C}_{1}$ & $\mathrm{C}_{4}$ & $\mathrm{C}_{3}$ \\
\hline & & $I_{2}$ & $\mathrm{C}_{1}$ & $\mathrm{C}_{2}$ & $\mathrm{C}_{3}$ & $\mathrm{C}_{4}$ & $I_{3}$ & $\mathrm{C}_{3}$ & $\mathrm{C}_{4}$ & $\mathrm{C}_{2}$ & $\mathrm{C}_{1}$ \\
\hline
\end{tabular}

South

Figure 1: The field plan and experimental arrangement

$\mathrm{I}_{1}, \mathrm{I}_{2}, \mathrm{I}_{3}, \mathrm{I}_{4}$ : irrigation after $70,100,130$ and $160 \mathrm{~mm}$ evaporation, respectively.

$\mathrm{C}_{1}, \mathrm{C}_{2}, \mathrm{C}_{3}, \mathrm{C}_{4}$ : Faraman, Goldasht, Sina and Soffeh cultivars, respectively. 
Seeds of Safflower (Carthamus tinctorius L.) were sown by hand on 23rd April 2013 in $4 \mathrm{~cm}$ depth of a sandy loam soil. Each plot consisted of 10 rows of $3 \mathrm{~m}$ length, spaced $25 \mathrm{~cm}$ apart. Seeding rate was 100 seeds per $\mathrm{m}^{2}$. All plots were irrigated immediately after sowing. Subsequent irrigations were carried out on the bases of proposed evaporation from class A pan. Hand weeding of the experimental area was performed as required.

After seed formation, 5 plants from each plot were harvested in 5 days intervals at seven stages. Then seeds were detached from the capitol and seeds were air dried at $18-20^{\circ} \mathrm{C}$ and mean seed mass of each sample was determined.

Four replicates of 50 seeds from each sample were weighted $\left(\mathrm{SW}_{1}-\mathrm{SW}_{4}\right)$ and then seeds of each replicate immersed in $250 \mathrm{ml}$ deionized water in a container at $20{ }^{\circ} \mathrm{C}$ for 24 hours. The seed-steep water was then gently decanted and electrical conductivity (EC) of seed leachates was measured, using an $\mathrm{EC}$ meter $\left(\mathrm{EC}_{1}-\mathrm{EC}_{4}\right)$. Following equation was applied to calculate the conductivity per gram of seed mass for each sample (Powell et al., 1984).

$\mathrm{EC}(\mu \mathrm{s} / \mathrm{cm} / \mathrm{g})=\left[\left(\mathrm{EC}_{1} / \mathrm{SW}_{1}\right)+\cdots \cdot+\left(\mathrm{EC}_{4} / \mathrm{SW}_{4}\right)\right] / 4$
Seed samples within separate sealed bags were then placed in a refrigerator at $3-5^{\circ} \mathrm{C}$. Seed vigor tests were carried out at the seed Technology Laboratory of the University of Tabriz.

Four replicates of 25 seeds from each sample were treated with 2 g.kg ${ }^{-1}$ Benomyl, before testing. Seeds of each replicate were placed between two $30 \times 30 \mathrm{~cm}$ wetted and rolled filter papers, which were then placed in plastic bags to prevent water loss. These bags were incubated at $20 \pm 1{ }^{\circ} \mathrm{C}$ and germinated seeds (protrusion of seminal root by $2 \mathrm{~mm}$ ) were counted every day up to 8 days. Seed germination rate was calculated according to Ellis and Roberts (1980):

$$
R=\sum n_{i} \sum D n
$$

Where $n$ is number of seeds germinated on each day, $D$ is the number of days from the beginning of the test and $R$ is the mean germination rate. At the end of test, normal seedlings were dried in an oven at $75^{\circ} \mathrm{C}$ for 48 hours (Perry, 1977) and mean seedling dry mass for each treatment at each replicate was recorded.

Analyses of variance and comparison of means at $\mathrm{P} \leq 0.05$ were performed, using SAS 9.1 software. Excel software was used to draw figures.

\section{RESULTS}

Seed mass and electrical conductivity of seed leachates were significantly affected by Irrigation, cultivar, harvest time and interactions of these factors $(p \leq 0.01)$. Seed germination rate significantly influenced by irrigation and harvest time $(p \leq 0.01)$ and also by interaction of cultivar $\times$ harvest time $(p \leq 0.05)$. The effects of cultivar, harvest time and interaction of these factors were also significant for seedling dry mass $(p \leq 0.01)$. Thus, regression curves were fitted on mean data of significant interactions in order to show the changes in parameters of seed vigor at different stages of seed development and maturity (Figs. 2$5)$.

Seed weight of safflower cultivars under different irrigation treatments increased with progressing seed development up to a point where maximum mass was obtained. In most cases, mass maturity (end of seed filling phase) were achieved at about 40 days after flowering and thereafter, no considerable changes were occurred. Seed moisture content at these stages was $15-20 \%$, depending on water supply. Seed mass at early stages of development under $\mathrm{I}_{3}$ and $\mathrm{I}_{4}$ was higher, but at later stages of development was lower than that under well watering $\left(\mathrm{I}_{1}\right)$. The highest and the lowest seed mass at all stages of seed development under different irrigation intervals were recorded for Faraman and Sina cultivars, respectively. Changes in seed mass of 'Goldasht' and 'Soffeh' under different treatments were almost similar (Fig. 2). 

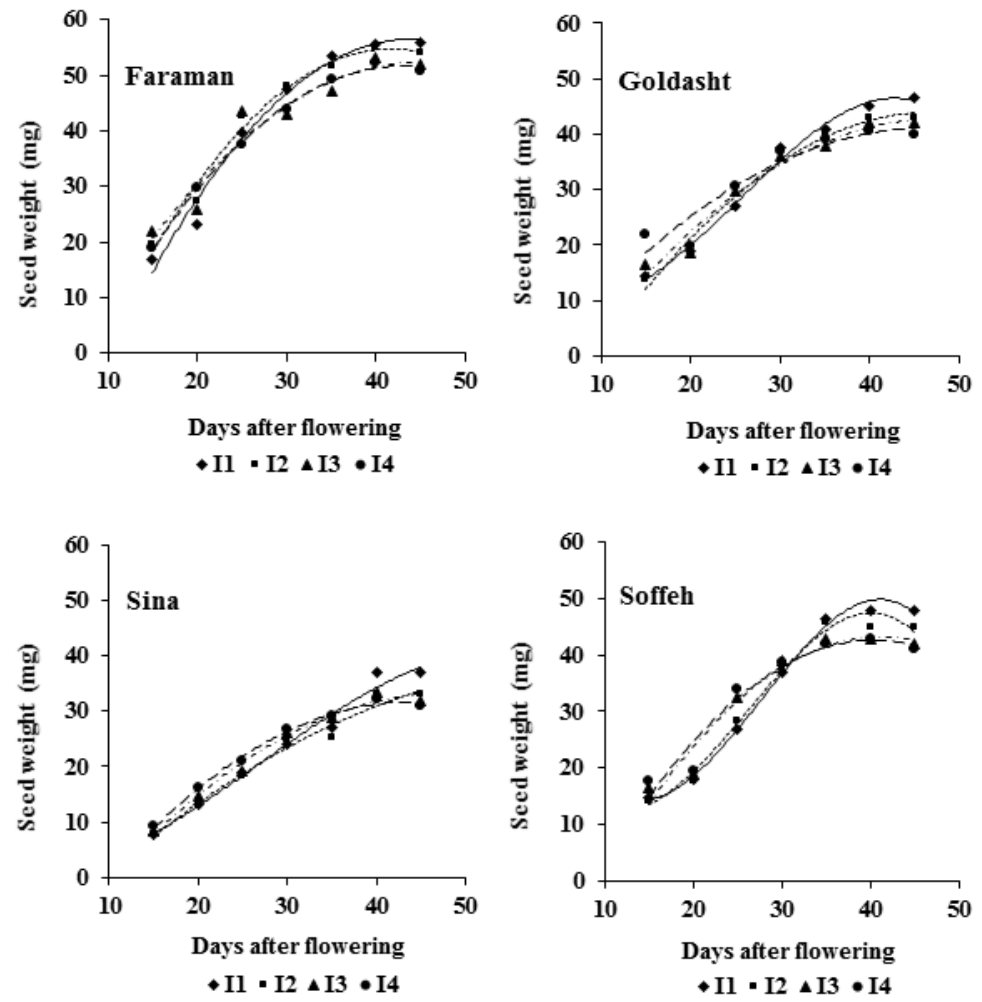

Figure 2: Changes in seed mass of spring safflower cultivars during seed development and maturity under different irrigation intervals

$\mathrm{I}_{1}, \mathrm{I}_{2}, \mathrm{I}_{3}, \mathrm{I}_{4}$ : irrigation after $70,100,130$ and $160 \mathrm{~mm}$ evaporation, respectively.

Electrical conductivity (EC) of seed leachates for all safflower cultivars under different irrigation intervals decreased with improving seed development. In most cases, minimum electrical conductivity of seeds produced for all cultivars under all irrigations were obtained at 40-43 days after flowering, with slight increase thereafter. The highest electrical conductivity of seed leachates was recorded for seeds produced under $\mathrm{I}_{4}$, which decreased with increasing water supply (Fig. 3).
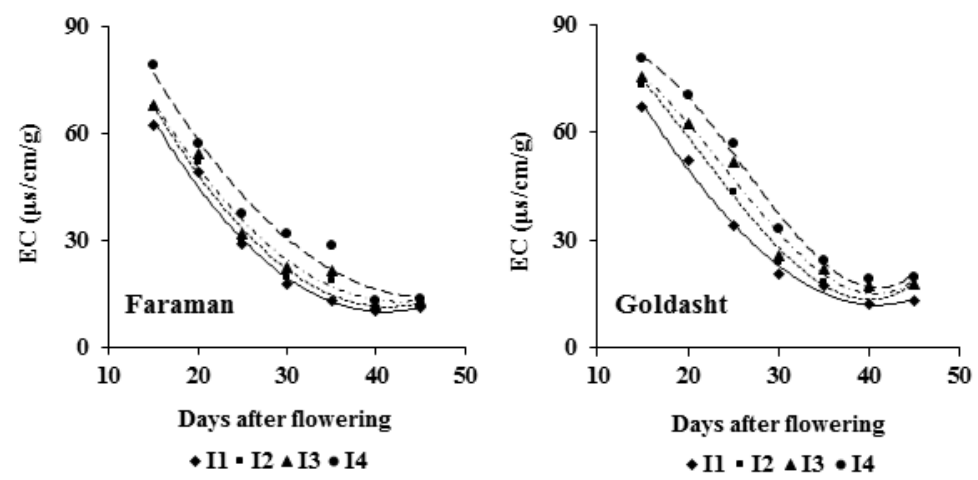

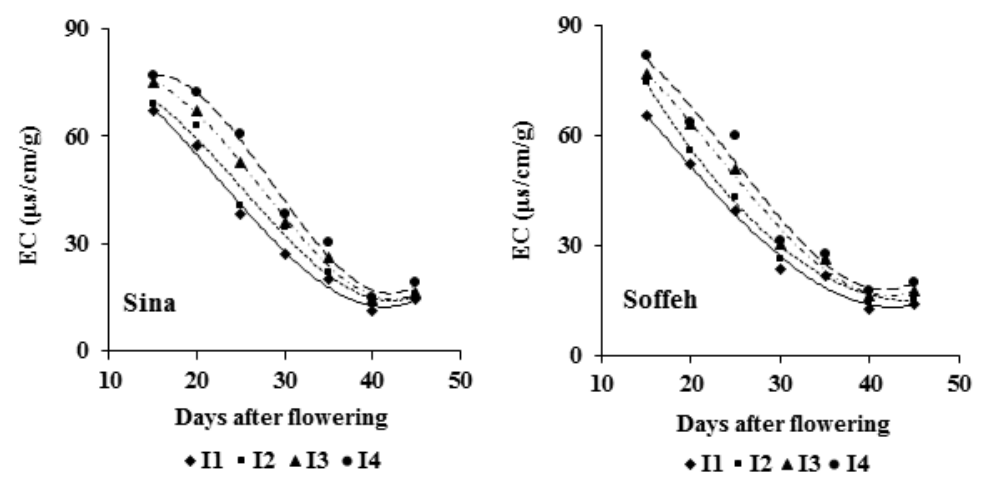

Figure 3: Electrical conductivity of seed leachates for spring safflower cultivars during seed development and maturity under different irrigation intervals

$\mathrm{I}_{1}, \mathrm{I}_{2}, \mathrm{I}_{3}, \mathrm{I}_{4}$ : irrigation after $70,100,130$ and $160 \mathrm{~mm}$ evaporation, respectively

Seed germination rate of all safflower cultivars increased up to final harvest. Therefore, maximum seed germination rate of safflower cultivars was attained at 45 days after flowering. 'Sina' had the highest seed germination rate at two earlier harvest, but the lowest germination rate at three later harvests. Seed germination rate of other three cultivars at later stages of development was almost similar (Fig. 4).

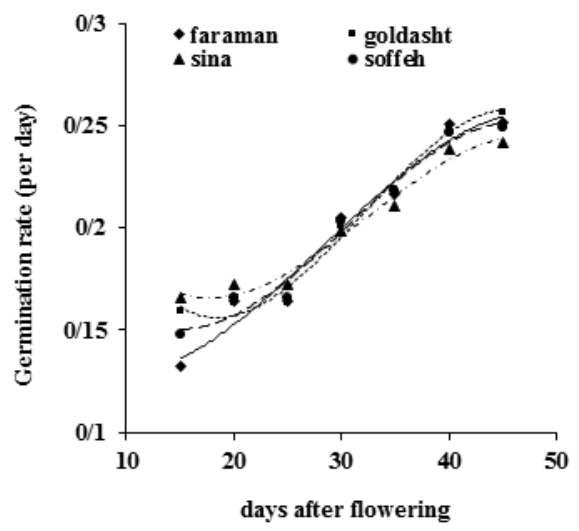

Figure 4: Changes in seed germination rate of safflower cultivars during seed development and maturity

'Faraman' had the highest, but 'Sina' had the lowest seedling dry mass from seeds produced under all irrigation intervals, with no considerable difference between 'Goldasht' and 'Soffeh'. Seedling dry mass of seeds produced under severe water deficit showed an increase for Faraman and a decrease for Sina and Soffeh cultivars (Fig. 5a). Seedling dry mass of safflower cultivars at the early stages of seed development was low, but it was improved progressively with seed development up to 40 days after flowering, and thereafter slightly decreased. Faraman and Sina cultivars had the highest and the lowest seedling dry mass at all stages of seed development, respectively, while seedling dry mass of Goldasht and Soffeh at different harvest times was similar (Fig. 5b). 

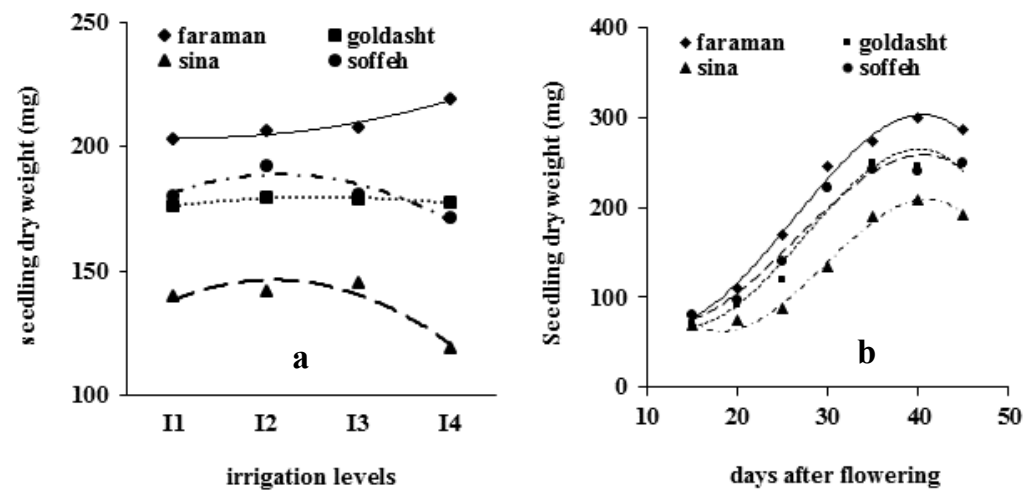

Figure 5: Changes in seedling dry mass for seeds of safflower cultivars produced under different irrigation intervals (a) and harvesting times (b)

$\mathrm{I}_{1}, \mathrm{I}_{2}, \mathrm{I}_{3}, \mathrm{I}_{4}$ : irrigation after $70,100,130$ and $160 \mathrm{~mm}$ evaporation, respectively

Maximum seed mass and minimum electrical conductivity of seed leachates were significantly influenced by irrigation intervals $(p \leq 0.05)$ and cultivars $(\mathrm{p} \leq 0.01)$. Differences in maximum seedling dry mass of safflower cultivars were also significant $(p \leq 0.01)$. Maximum seed mass decreased, but minimum electrical conductivity increased with increasing irrigation intervals. The highest seed and seedling dry mass and the lowest electrical conductivity were recorded for seeds of 'Faraman'. In contrast, the smallest seeds and seedlings were observed in Sina cultivar (Table 1).

Table 1: Means of minimum values of electrical conductivity and maximum values of the other seed vigor parameters for different irrigation intervals and safflower cultivars

\begin{tabular}{ccccc}
\hline Treatments & $\begin{array}{c}\text { Seed mass } \\
(\mathbf{m g})\end{array}$ & $\begin{array}{c}\text { Electrical } \\
\text { conductivity } \\
(\boldsymbol{\mu s} / \mathbf{c m} / \mathbf{g})\end{array}$ & $\begin{array}{c}\text { Germination } \\
\text { rate } \\
\text { (per day) }\end{array}$ & $\begin{array}{c}\text { Seedling } \\
\mathbf{d r y} \\
\text { mass }(\mathbf{m g})\end{array}$ \\
\hline Irrigations & & & & \\
$\mathrm{I}_{1}$ & $47.56 \mathrm{a}$ & $11.31 \mathrm{~b}$ & $0.256 \mathrm{a}$ & $262.57 \mathrm{a}$ \\
$\mathrm{I}_{2}$ & $44.96 \mathrm{ab}$ & $12.99 \mathrm{ab}$ & $0.249 \mathrm{a}$ & $266.87 \mathrm{a}$ \\
$\mathrm{I}_{3}$ & $43.03 \mathrm{bc}$ & $13.42 \mathrm{a}$ & $0.262 \mathrm{a}$ & $272.05 \mathrm{a}$ \\
$\mathrm{I}_{4}$ & $41.89 \mathrm{c}$ & $14.39 \mathrm{a}$ & $0.251 \mathrm{a}$ & $259.65 \mathrm{a}$ \\
\hline Cultivars & & & & \\
$\mathrm{C}_{1}$ & $54.27 \mathrm{a}$ & $10.82 \mathrm{~b}$ & $0.256 \mathrm{a}$ & $307.88 \mathrm{a}$ \\
$\mathrm{C}_{2}$ & $44.06 \mathrm{~b}$ & $14.78 \mathrm{a}$ & $0.260 \mathrm{a}$ & $266.07 \mathrm{~b}$ \\
$\mathrm{C}_{3}$ & $33.79 \mathrm{c}$ & $11.70 \mathrm{~b}$ & $0.248 \mathrm{a}$ & $224.78 \mathrm{c}$ \\
$\mathrm{C}_{4}$ & $45.33 \mathrm{~b}$ & $14.82 \mathrm{a}$ & $0.254 \mathrm{a}$ & $262.40 \mathrm{~b}$ \\
\hline
\end{tabular}

$\mathrm{I}_{1}, \mathrm{I}_{2}, \mathrm{I}_{3}, \mathrm{I}_{4}$ : irrigation after $70,100,130$ and $160 \mathrm{~mm}$ evaporation, respectively.

$\mathrm{C}_{1}, \mathrm{C}_{2}, \mathrm{C}_{3}, \mathrm{C}_{4}$ : Farman, Goldasht, Sina and Soffeh cultivars, respectively.

Different letters in each column indicate significant difference at $\mathrm{p} \leq 0.05$

\section{DISSCUSION}

Water stress decreases photosynthetic production because of stomata closure and early senescence which ultimately reduces maximum seed mass (Fig. 1, Table 1). Reduction in seed mass due to water limitation is also reported for maize $(\mathrm{Ne}$ Smith and Ritchie, 1992), lentil (Erskine and
Ashkar, 1993), chickpea (Silim and Saxena, 1993), soybean (Desclaux and Roumet, 1996), wheat (Li et al., 2000) and barley (Samarah, 2005). Variation in seed mass among cultivars under different levels of watering (Fig. 1) is the result of differences in genetic constitution. Different sizes of seeds 
having different levels of food storage may be the important factor which influences seed vigor (Perry, 1980).

Maximum seed vigor as measured by electrical conductivity of seed leachate was obtained at about mass maturity or slightly after that stage, depending on cultivar and water supply. Earlier harvests due to immaturity, and later harvests because of aging reduced seed vigor of safflower cultivars under all treatments (Fig. 2). These results were supported by the reports on common bean (Ghassemi-Golezani and Mazloomi-Oskooyi, 2008) and faba bean (Ghassemi-Golezani and Hosseinzadeh-Mahootchy, 2009). Increasing electrical conductivity of seeds with decreasing water availability to the mother plants (Table 1), clearly suggest that the most vigorous seeds of this crop can be produced under well watering. In contrast, Ghassemi-Golezani and HosseinzadehMahootchy (2009) reported that drought stress had no significant effect on electrical conductivity of faba bean cultivars.

Maximum germination rate of all cultivars was achieved 5 days after mass maturity. Higher germination rate of Sina cultivar at early harvest and the lower germination rate of this cultivar at later harvests may be related with rapid seed development and maturity of that cultivar, compared with other cultivars (Fig. 3). Nevertheless, maximum germination rate was almost similar for all irrigation treatments and cultivars (Table 1).

Water limitation had no significant effect on seed vigor of safflower cultivars, as determined by seedling dry mass (Table 1). The highest and the lowest seedling dry mass of Faraman and Sina under different irrigation treatments (Fig. 4a) directly related with the seed size of these cultivars (Fig. 1). Several reports suggest that large seeds have greater and longer supply of stored reserves to support early seedling growth, leading to the production of larger seedlings (GhassemiGolezani, 1992; Ghassemi-Golezani et al., 2012a,b, 2015). Therefore, differences in seedling dry mass among safflower cultivars at different stages of seed development and maturity (Fig. 4b) were associated with variation in seed mass and genetic constitution, which can strongly influence seed and seedling vigor (Perry, 1980). The highest seedling dry weight of all cultivars was recorded at the end of seed filling phase or mass maturity (40 days after flowering) (Fig. 4b). Therefore, maximum seed vigor of safflower cultivars as measured by seedling dry mass was obtained at mass maturity under all irrigation treatments, which can be named physiological maturity as suggested by Harington (1972).

\section{CONCLUSION}

Seed size of safflower cultivars decreased, but electrical conductivity of seed leachates slightly increased as a result of water deficit. However, maximum germination rate and seedling dry mass were not significantly affected by water limitation. Therefore, high vigor seeds of this crop could be produced under different irrigation intervals, if seeds were harvested at or slightly after the end of seed filling phase (mass maturity) with a moisture content of about 15-20\%. Early and delayed harvests could lead to the production of low vigor seeds. Faraman was a superior cultivar in producing the highest vigor seeds under a wide range of water availability. It seems that safflower cultivars are adapted to semi-arid conditions and water stress has little effect on their seed vigor, provided the seeds are harvested at the right time. Similar research on different crops and environmental conditions may provide more information about producing high vigor seeds. 


\section{REFERENCES}

Abud H.F., Reis R.G.E., Innecco R., Bezerra A.M.E. 2010. Emergence and development of seedling of safflower depending on seed size. Revista Ciencia Agronomica, 41, 95-99.

Demir I., Ashirov A.M., Mavi K. 2008. Effect of seed production environment and time of harvest on tomato (Lycopersicon esculentum) seedling growth. Research Journal of Seed Science, 1, 1-10.

Desclaux D., Roumet P. 1996. Impact of drought stress on the phenology of two soybean (Glycine $\max \mathrm{L}$. Merr) cultivars. Field Crops Research, 46, 61-70. DOI: 10.1016/0378-4290(95)00086-0

Ellis R. H., Roberts E.H. 1980. Towards a rational basis for testing seed quality, pp. 605- 635. In: Hebblethwaite, P. D. (Eds.). Seed production. Butterworths, London.

Ellis R.H., Pieta Filho C. 1992. Seed development and cereal seed longevity. Seed Science Research, 2, 915.

Erskine W., Ashkar F.E. 1993. Rainfall and temperature effects on lentil (Lens culinaris Medik) seed yield in Mediterranean environments. Journal of Agriculture Science, 121, 347-354. DOI: $10.1017 / \mathrm{S} 0021859600085543$

Ghassemi-Golezani K. 1992. Effects of seed quality on cereal yields. PhD Thesis, University of Reading, UK. pp. 205-222.

Ghassemi-Golezani K., Akbari H., Bandeh-Hagh A. 2012a. Effects of plant density and pod position on seed vigour of pinto bean cultivars. Research on Crops, 13, 529-533.

Ghassemi-Golezani K., Chadordooz-Jeddi A., ZehtabSalmasi S. 2014. Effects of seed size and aging on field performance of lentil (Lens culinaris Medik.) under different irrigation treatments. Acta Agriculturae Slovenica, 103, 158 - 166. DOI: 10.14720/aas.2014.103.2.1

Ghassemi-Golezani K., Heydari Sh., Hassannejad S. 2015. Seed vigor of maize (Zea mays) cultivars affected by position on ear and water stress. Azarian Journal of Agriculture, 2, 40-45.

Ghassemi-Golezani K., Hossinzadeh-Mahootchy A. 2009. Changes in seed vigor of faba bean (Vicia faba L.) cultivars during development and maturity. Seed Science and Technology, 37, 713-720. DOI: 10.15258/sst.2009.37.3.18

Ghassemi-Golezani,K., Lotfi, R., Norouzi M. 2012b. Seed quality of soybean cultivars affected by pod position and water stress at reproductive stages.
International Journal of Plant, Animal and Environmental Sciences, 3, 119-125.

Ghassemi-Golezani K., Mazloomi-Oskooyi R. 2008. Effect of water supply on seed quality development in common bean (Phaseolus vulgaris). International Journal of Plant Production, 2, 117-124.

Ghassemi-Golezani K, Sheikhzadeh Mosaddegh P, Shakiba MR, Mohamadi A, Nasrollahzadeh S. 2011a. Development of seed physiological quality in winter oilseed rape (Brassica napus L.) cultivars. Not Bot Hort Agrobot Cluj. 39: 208-212.

Ghassemi-Golezani K, Tajbakhsh Z, Raey Y. 2011b. Seed development and quality in maize cultivars. Not Bot Hort Agrobot Cluj. 39, 178-182.

Ghassemi-Golezani K., Zafarani-Moattar P., Raey Y., Mohammadi A. 2010. Response of pinto bean cultivars to water deficit at reproductive stages. Journal of Food, Agriculture and Environment, 8, 801-804.

Hampton J.G., Johnstone K.A., Eua-Umpon V. 1992. Bulk conductivity test variables for mungbean, soybean and French bean seed lots. Seed Science and Technology, 20, 677-686.

Harington I.F. 1972. Seed storage and longevity. In: T.T. Kozlowski (ed.). Seed Biology Volume 111. New York Academic Press, pages 145-245. DOI: 10.1016/b978-0-12-395605-7.50009-0

Li A.G., Hou V.S., Wall G.W., Trent A., Kimball B.A., Printer P.J. 2000. Free-air $\mathrm{CO}_{2}$ enrichment and drought stress effect on grain filling rate and duration in spring wheat. Crop Science, 40, 12631270. DOI: $10.2135 /$ cropsci2000.4051263x

Monotti M. 2003. Growing non-food sunflower in dryland conditions. Italian Journal of Agronomy, 8 , 3-8.

Ne Smith D.S., Ritchie J.T. 1992. Maize (Zea mays L.) response to a sever soil water deficit during grain filling. Field Crops Research, 29, 23-35. DOI: 10.1016/0378-4290(92)90073-I

Perry D.A. 1977. A vigor test for seeds of barley (Hordeum vulgar) based on measurement of plumule growth. Seed Science and Technology, 5, $709-719$

Perry D.A. 1980. Deterioration of barley seed and its effects on field performance, p. 321-337. In: Hebblethwaite PD (Ed.). Seed Production. Butterworths. 
Powell A.A., Matthews S., Oliveira A. 1984. Seed quality in grain legumes. Annals of Applied Biology, 10, 217-285.

Samarah N.H. 2005. Effects of drought stress on growth and yield of barley. Agronomy for Sustainable Development, 25, 145-149. DOI: 10.1051/agro:2004064

Silim S.N., Saxena M.C. 1993. Adaptation of spring sown chickpea to the Mediterranean basin. II Factors influencing yield under drought. Field Crops Research, 34, 137-146. DOI: 10.1016/03784290(93)90002-5

Sun Q., Wang J.H., Sun B.Q. 2007. Advances in seed vigor physiological and genetic mechanisms. Agricultural Sciences in China, 6, 1060-1066. DOI: 10.1016/S1671-2927(07)60147-3
Tekrony D.M., Egli D.B. 1991. Relationship of seed vigor to crop yield: A Review. Crop Science, 31, $816-$ 822. DOI: 10.2135/cropsci1991.0011183X003100030054x

Tekrony D.M., Egli D.B. 1997. Accumulation of seed vigor during development and maturation. In Basic and applied aspects of seed biology, (eds. R.H. Ellis, M. Black, A.J. Murdoch and T.D. Hong), Kluwer Academic Publishers, Dordrecht, pp. 369384. DOI: 10.1007/978-94-011-5716-2_41

Vieira R.D., Tekrony D.M., Egli D.B. 1992. Effect of drought and defoliation stress in the field on soybean seed germination and vigor. Crop Science, 32, 471-475. DOI: 10.2135/cropsci1992.0011183X003200020037x 